Т.В. Смірнова ${ }^{1}$, М.П. Столяренко ${ }^{2}$, М.О. Янков ${ }^{1}$, В.В. Грудік ${ }^{1}$, Ю.Ю. Моторін ${ }^{1}$

${ }^{1}$ Центральноукраӥнський національний технічний університет, Кропивницький

${ }^{2}$ Науково-дослідний цеентр ракетних військ і артилерії, Суми

\title{
МОДЕЛЬ РЕАЛІЗАЦІЇ СТРУКТУРИ ТЕХНОЛОГІЧНОГО ПРОЦЕСУ У ХМАРНОМУ СЕРВІСІ
}

У роботі розроблено модель реалізації структури технологічного прочесу у хмарному сервісі, для якої було визначено основні вхідні параметри: перелік параметрів, які впливають на прочес; перелік параметрів, які є результатом процесу; перелік керованих параметрів; перелік некерованих параметрів; перелік невідомих параметрів; деталізована структура технологічного процесу з розділенням параметрів та результатів. Запропонована структура експертної системи для оптимізації технологічних процесів, проаналізовані методи представлення знань та відповідно розроблено схему потоків інформачії під час реалізації даної експертної системи. На основі розглянутих та розроблених методів та механізмів, які використовують для розробки технологічних процесів, розроблено структуру інформаційної системи підтримки прийняття рішень для автоматизації створення оптимізованих технологічних процесів. За допомогою використання розроблених методів та моделей, в результаті проведення процесу оптимізаиії технологічного процесу за допустимими евристичними правилами, вдалося отримати множину ланщюгів окремо оптимізованих технологічних процесів, з якої проводиться багатокритеріальний відбір, щзо відповідає поставленим вимогам оптимізації. Користувач системи може отримувати у відповідь як одну картку технологічного процесу, так і декілька найкращчх. Таким чином розроблена у даній роботі модель реалізації структури технологічного процесу дозволяє у подальшому оптимізувати високотехнологічні процеси підприємств різного маситабу з використання хмарних інформачійних технологій.

Ключові слова: система підтримки прийняття рімень, технологічні процеси, хмарні сервіси.

\section{Вступ}

Постановка проблеми. Складність технічних систем, що моделюються, значною мірою залежить від різноманіття номенклатури об’єктів вимірювання, наявних вимірювальних приладів і систем, та багатьох інших умов. При цьому завжди намагаються використовувати такі технологічні процеси, за допомогою яких можна досягати найбільшої продуктивності праці за найменшої собівартості та високої якості продукції в умовах певного підприємства. До системного аналізу входять [1-3]:

1. Постановка задачі, яка включає визначення кінцевих цілей та питання, що потребують вирішення умов, в яких функціонує система, визначення обмежень, що накладаються на умови функціонування системи та ін.

2. Дослідження: визначення, аналіз і узагальнення даних, необхідних для розв'язання задачі, визначення структури системи (проблеми), що аналізується, установлення зв'язків, виявлення методів та дій для розв'язання задачі.

3. Аналіз, що охоплює побудову моделей, вибір критеріїв ефективності їх використання для передбачення наслідків того чи іншого курсу дій, зіставлення різних варіантів рішень щодо цих наслідків.

4. Попереднє судження зводиться до вибору найоптимальніших шляхів досягнення мети, формулювання висновків та розроблення рекомендацій щодо подальших дій.

5. Експериментальна перевірка ухвалених рішень, результатів аналізу.

6. Заключне судження - заключний вибір найоптимальнішого варіанта вирішення завдання на підставі експериментальної перевірки результатів аналізу.

7. Реалізація ухваленого рішення, що включає доведення ухваленого рішення до конкретних результатів: креслень, технологій, організаційних заходів тощо.

В загальному випадку, вхідними параметрами до моделі реалізації структури технологічного процесу є [6]:

- перелік параметрів, які впливають на процес;

- перелік параметрів, які є результатом процесу;

- перелік керованих параметрів;

- перелік некерованих параметрів;

- перелік невідомих параметрів;

- деталізована структура технологічного процесу з розділенням параметрів та результатів.

В даній роботі метою формування моделі реалізації структури технологічного процесу є забезпе- 
чення можливості створення універсальних алгоритмів і програм щодо початкових і кінцевих умов, тобто щодо форми і розмірів деталей, характеру виробництва, характеристик устаткування і оснащення, проектуванні різних технологічних процесів для деталей різних класів і будь-якої складності й їх реалізація у вигляді хмарного сервісу.

Аналіз останніх досліджень і публікацій. Сучасні високотехнологічні підприємства можуть сягати дуже великих розмірів, й відповідно технологічні процеси, які на них забезпечуються, можуть мати дуже складні розгалужені структури [1; $4 ; 8 ; 11 ; 16]$.

В залежності від типу виробництва, наявної інфраструктури, використовуваних методів, тощо, комплексний опис, реалізація та моніторинг технологічних процесів може бути дуже складною задачею, для вирішення якої необхідно застосовувати різноманітні методи дослідження.

Зважаючи на це, можна виділити дуже перспективний напрям щодо оптимізації високотехнологічних процесів, а саме використання хмарних інформаційних технологій для оптимізації виробничих процесів підприємств різного масштабу. Проте все одно залишається ряд невирішених проблем під час використання хмарних технологій для оптимізації виробничих процесів, що пов'язані із формалізацією самих виробничих процесів, вибором методів оптимізації, моніторингом всіх процесів, захистом даних щодо виробничих процесів, тощо.

У роботах $[1 ; 7]$ розглянуто хмарну автоматизовану систему інтелектуальної підтримки прийняття рішень для технологічних процесів, та визначено область застосування таких систем. Роботи $[4 ; 8 ; 13 ; 15 ; 16]$ обгрунтовують застосування систем підтримки прийняття рішень для реалізації технологічних процесів. Використання у задачах даного класу експертних систем обгрунтовано у роботах $[2 ; 5 ; 15-16]$.

Опис технологічних операцій для різних технологічних процесів наведено у роботах $[6 ; 8 ; 11 ; 14]$. Формування баз даних та баз знань для відповідних систем обгрунтовані у роботах [2; 9]. Таким чином проведений аналіз підтверджує необхідність розробки моделі реалізації структури технологічного процесу у хмарному сервісі, для практичного застосування у розроблювальних у подальшому системах підтримки прийняття рішень при автоматизації процесів формування та відновлення деталей.

Мета статті - полягає в розробці моделі реалізації структури технологічного процесу у хмарному сервісі, що дозволить у подальшому оптимізувати високотехнологічні процеси підприємств різного масштабу з використання хмарних інформаційних технологій.

\section{Виклад основного матеріалу}

\section{Абстрактний технологічний процес, його властивості та методи переходу до конкретного технологічного процесу}

Технологічний процес складається 3 ланцюга окремих технологічних операцій, кожна з яких через різні причини може бути замінена на технологічну операцію на іншій основі, але аналогічну за отриманим результатом.

Для будь-якого етапу обробки, характерна технологічна спадковість, коли використання обробки обмежується за рахунок умов, накладених попередньою використаною операцією.

Проблемою $є$ часткова технологічна спадковість, коли такі операції частково перекривають кілька попередніх, що значно ускладнює повний граф можливих ланцюгів проведених операцій.

Для оптимізації технології по ланцюгу технологічного процесу використовують експертні системи, загальна структура яких показана на рис. 1.

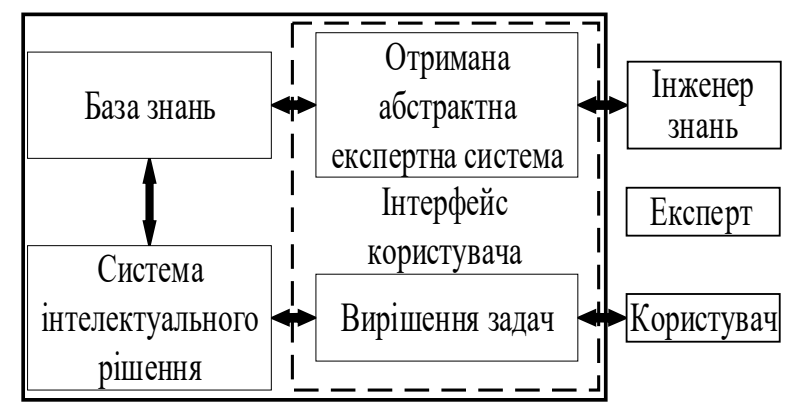

Рис. 1. Представлення експертної системи для оптимізації технологічних процесів Джерело: розроблено авторами.

У схемі використані такі позначення:

- експерт - фахівець з даної технологічної операції;

- інженер знань-фахівець, який формалізує знання експертів, відповідає за процес отримання знань і надання їх до бази знань експертної системи;

- база знань - множина доступних знань щодо обраної технологічної операції;

- система інтелектуального рішення ключовий елемент експертної системи, який на основі наявних знань і вхідних параметрів поставленого завдання надає параметри технологічного процесу з оптимізацією заданими критеріями (час роботи, доступні матеріали, сукупні грошові витрати);

- інтерфейс користувача відповідає за взаємодію між комп'ютерними системами і людиною.

У свою чергу експертні системи на основі об'єктного підходу до класифікації методів представлення знань можна представити в наступному вигляді (рис. 2). 


\begin{tabular}{|c|c|c|c|}
\hline & \multicolumn{2}{|c|}{ Методи представлення знань } & \\
\hline \multicolumn{2}{|c|}{ Правила } & \multicolumn{2}{|c|}{ Об'єкти } \\
\hline \multirow{2}{*}{$\begin{array}{c}\text { Логістична } \\
\text { модель }\end{array}$} & \multirow{2}{*}{$\begin{array}{c}\text { Продуктивна } \\
\text { модель }\end{array}$} & \multirow{2}{*}{$\begin{array}{c}\text { Семантична } \\
\text { мережа }\end{array}$} & \multirow{3}{*}{$\begin{array}{c}\text { Фрейми } \\
\text { Об'єктно- } \\
\text { орієнтована } \\
\text { модель }\end{array}$} \\
\hline & & & \\
\hline \multicolumn{3}{|c|}{\begin{tabular}{|l|l|} 
Нечітка логіка Умовні ймовірності \\
\end{tabular}} & \\
\hline
\end{tabular}

Статистичні Динамічні

Рис. 2. Методи представлення знань в експертних системах

Джерело: розроблено авторами.

\section{Інформаційна модель технологічного процесу і методи її одержання}

В процесі побудови експертних систем оптимізації технологічного процесу необхідно пройти наступні етапи:

1. Визначення вхідних / вихідних даних.

2. Розробка словника атрибутів, які притаманні обраній технологічній операції.

3. Виявлення об'єктів і понять.

4. Виявлення зв'язків між вхідними керованими і некерованими параметрами технологічних операцій.

5. Визначення цілей оптимізації.

6. Визначення стратегій вибору параметрів технологічної операції для досягнення поставлених оптимізаційних задач. Виникає потреба у функціональному пов'язування вхідних даних і певних некерованих величин 3 параметрами, необхідними від технологічного процесу. Побудова експертної системи вимагає наявності співвідношень для знаходження параметрів, які оптимізуються, наприклад, грошові витрати, час обробки і витрачений вихідний ресурс відповідно:

$$
G(\vec{Y}), T(\vec{Y}), E(\vec{Y}) .
$$

Для технологічного процесу (1) на основі математичної моделі і розрахунку витрат на його виконання наводиться експертна система оптимізації технологічного процесу. Схема передбачає наявність ітераційного пошуку методом поступового поліпшення результату з початкового допустимого режиму роботи системи. Для більш надійного результату, при наявності значної нелінійності, такий процес можна проводити з кількох початкових точок. Таким чином можна перерахувати наступні складові інформаційного забезпечення функціонування експертної системи.

1. База знань, яка містить: дані експериментів, допустимі діапазони вхідних даних, список вхідних параметрів, список вихідних параметрів, методи i математичне забезпечення розрахунків витрат на процес.

2. Система отримання вимог до результатів відновлення і критерій (або критерії) оптимізації.

3. Система пошуку екстремумів в багатовимірному просторі.

4. Система перевірки на досягнення результату.

5. Система виявлення “зацикленості” пошуку рішень у випадках недосяжності поставлених вимог.

6. Система введення неконтрольованих вхідних параметрів.

7. Система забезпечення інформаційного потоку між компонентами експертної системи з урахуванням синхронізації і взаємних блокувань.

На рис. 3 представлено рух інформації в експертній системі оптимізації технологічного процесу.

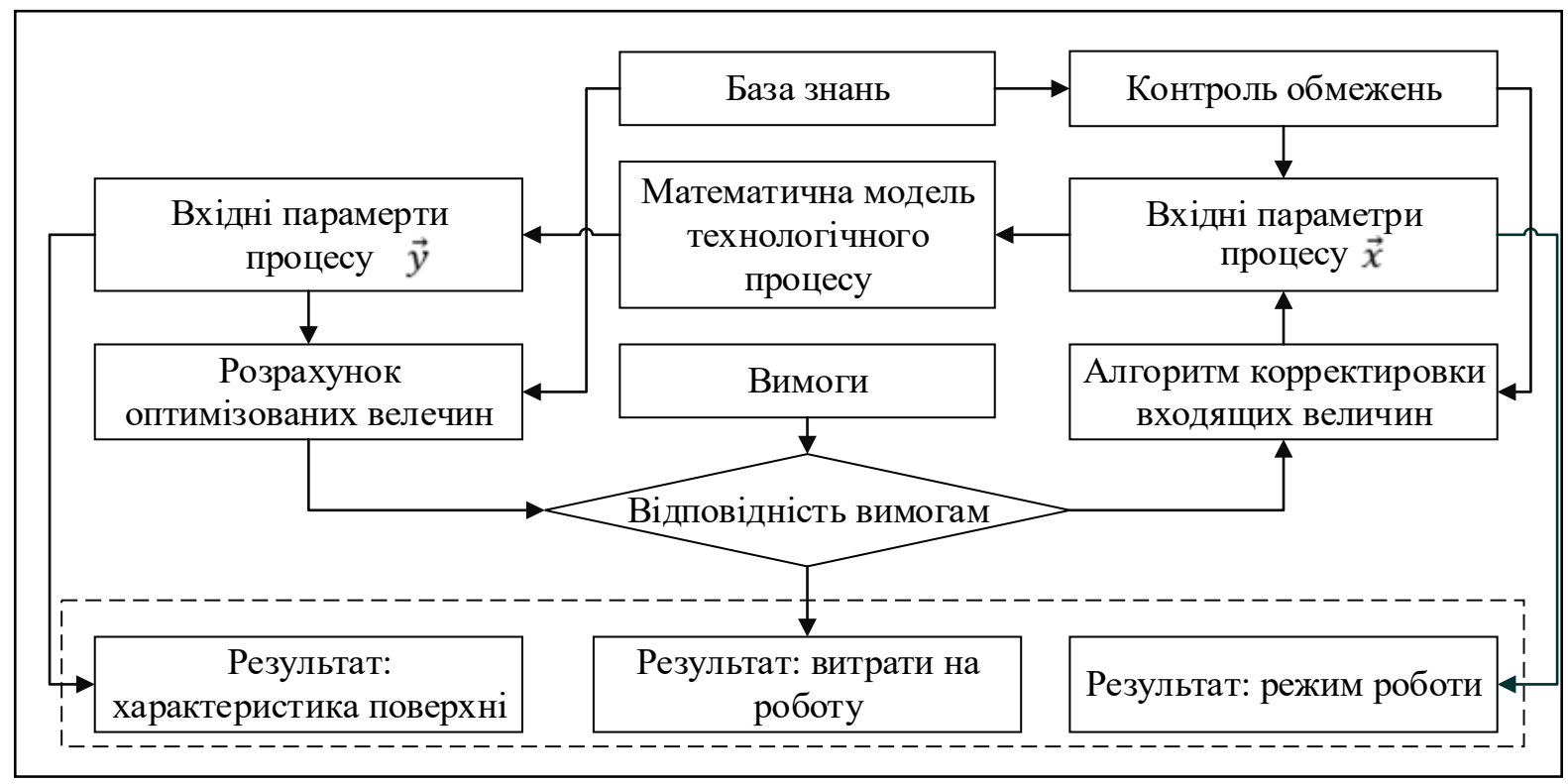

Рис. 3. Потоки інформації під час реалізації експертної системи Джерело: розроблено авторами.

\author{
Формалізація структури та правил \\ технологічного процесу, зведення до \\ універсального технологічного процесу
}

Структура управління виробничою інформацією повинна підтримувати користувача в діяльності 3 моделювання виробництва і постачати інструменти 
підтримки прийняття рішень необхідною інформацією. В процесі формування структури технологічного процесу потрібно визначити низку параметрів, які не регламентуються вимогами до готового виробу, але їх значення суттєво впливають на результат планування технологічних операцій. Також, не регламентовані вимоги не можуть бути виражені ні математично або алгоритмічно, і виводяться з власного досвіду експертів.

Інформаційна система забезпечення проектування технологічного процесу повинна забезпечити правильність заповнення вимог до результатів технологічного процесу. Тут система повинна забезпечити контроль повноти та сумісності вхідних даних, проводити контроль наявності вимог, які не можна визначити із вже заданих критеріїв. Також система повинна забезпечити можливість залишити вимогу невизначеною, якщо з вже визначених величин можлива оцінка цієї вимоги.

Особливе значення має можливість для необов'язкових вимог встановлювати критерії максимальності або мінімальності, при одночасному задоволенні інших критеріїв. Деякі вхідні параметри та вимоги мають характер визначення підмножини 3 доступних елементів. Очевидним критерієм вимог до результату технологічного процесу є можливість завдання граничних критеріїв. На основі математичного співвідношення (1) і діаграми потоку інформації в узагальненій експертній системі технологічного процесу (рис. 4) приведено приклад формалізації підмножини абстрактних експертних систем оптимізації технологічних процесів. Для цього використано такі позначення множин, які формують базу знань для ряду технологічних процесів: $S=\langle X, Y, V, M, P, D, G\rangle$, що включає операцію виділення підмножин елементів, що стосуються окремої технологічної операції $k$ :

1. $X_{k}$-множина керованих параметрів технологічного процесу $k$.

2. $Y_{k}$ - множина параметрів деталі, які контролює або змінює технологічний процес $k$.

3. $V_{k}$ - множина параметрів, які не справляються, але які необхідно враховувати при виконанні технологічного процесу $k$.

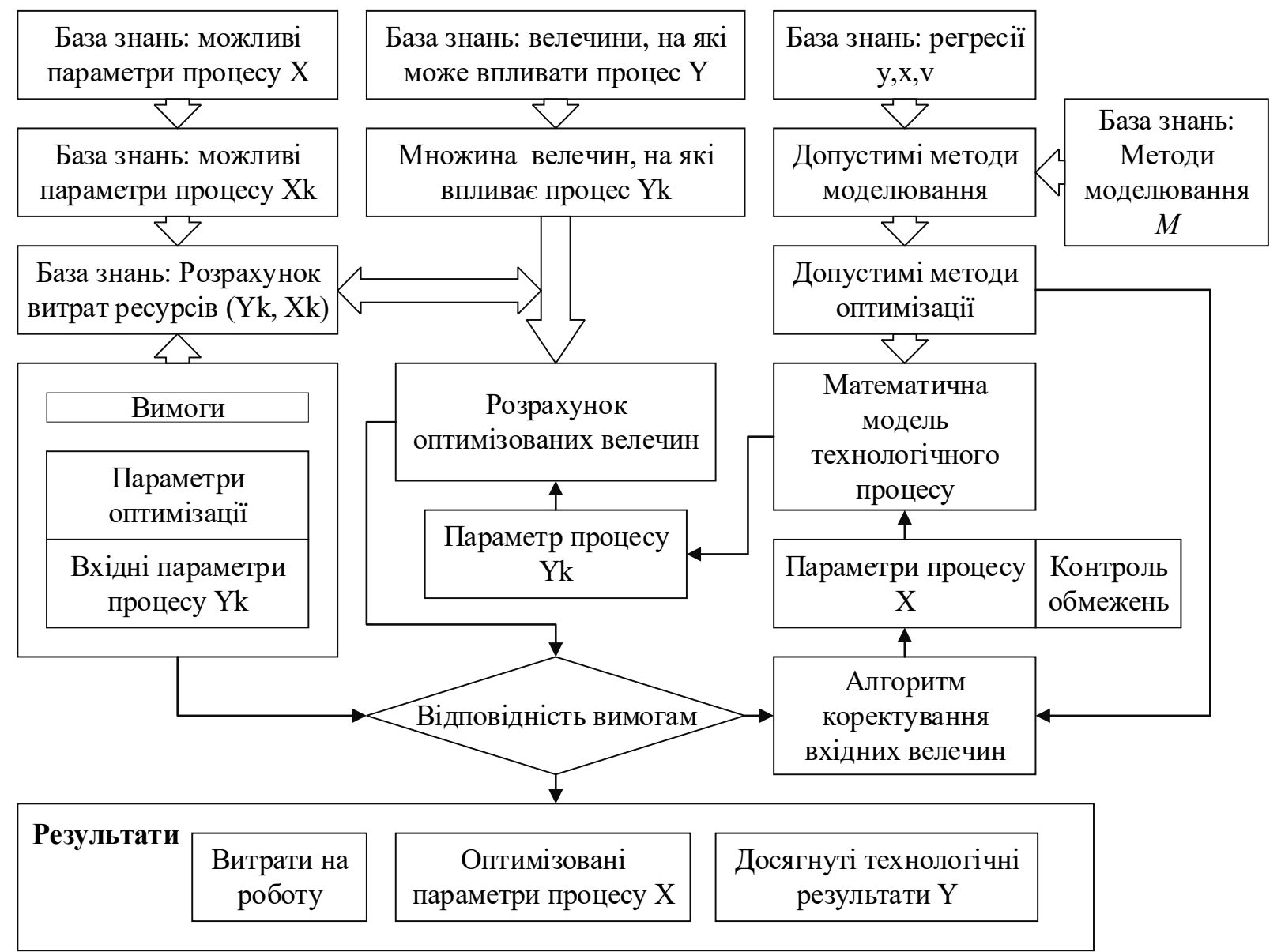

Рис. 4. Діаграма потоку інформації в реалізації узагальненої $k$-ї експертної системи оптимізації технологічного процесу

Джерело: розроблено авторами. 
4. $M_{k}$ - множина методів отримання математичної моделі технологічного процесу $k$.

5. $P(m), m \subset P\left(M_{k}\right)$ - обраний екземпляр з методів оптимізації, який можна застосувати для зазначених математичних моделей, $P$ - операція вибору методу 3 множини методів. Операція вибору може проводитися автоматично або по вибору розробника експертної системи.

6. $D_{k}$ - множина функцій розрахунку матеріальних, в т.ч. і часових, витрат на здійснення технологічного процесу $k$, за якими може проводитися процес оптимізації. Сюди ж входять лінійні або більш складні комбінації для отримання остаточної багатофакторної вагової оптимізаційної функції.

7. $G_{k}$ - множина матеріальних ресурсів, використовуваних у технологічному процесі.

Знаком вектору, як це зроблено в попередньому пункті, на відповідних позначеннях визначалися конкретний кортеж реальних величин, які відповідають безлічі обраних величин і характеристик.
Тоді отримаємо (рис. 4) наступні співвідношення для окремого технологічного процесу $k$ :

$$
\left\{\begin{array}{c}
\vec{X}_{k}=m\left(\vec{Y}_{k}, \vec{V}_{k}, \vec{Y}_{k-1}, \vec{G}_{k}\right) ; \\
\vec{G}_{k}=D_{k}\left(\vec{Y}_{k}, \vec{V}_{k}\right) ; \\
\left|\vec{G}_{k}\right| \rightarrow \min ; \\
\left|\vec{G}_{k}\right|=\infty, \quad \text { якщо } \vec{Y}_{k-1} \notin \vec{Y}_{k} .
\end{array}\right.
$$

Сукупність технологічних процесів $S$ і формують формальне завдання безлічі технологічних процесів. Додавання до бази знань нового технологічного процесу супроводжується наступними операціями:

$$
S=S \bigcup S_{k}, S_{k}=\left\langle X_{k}, Y_{k}, V_{k}, M_{k}, P_{k}, D_{k}, G_{k}\right\rangle,
$$

де $k$-номер доданого до системи технологічного процесу.

Графічне зображення формування окремої інформаційної моделі представлено на рис. 5.

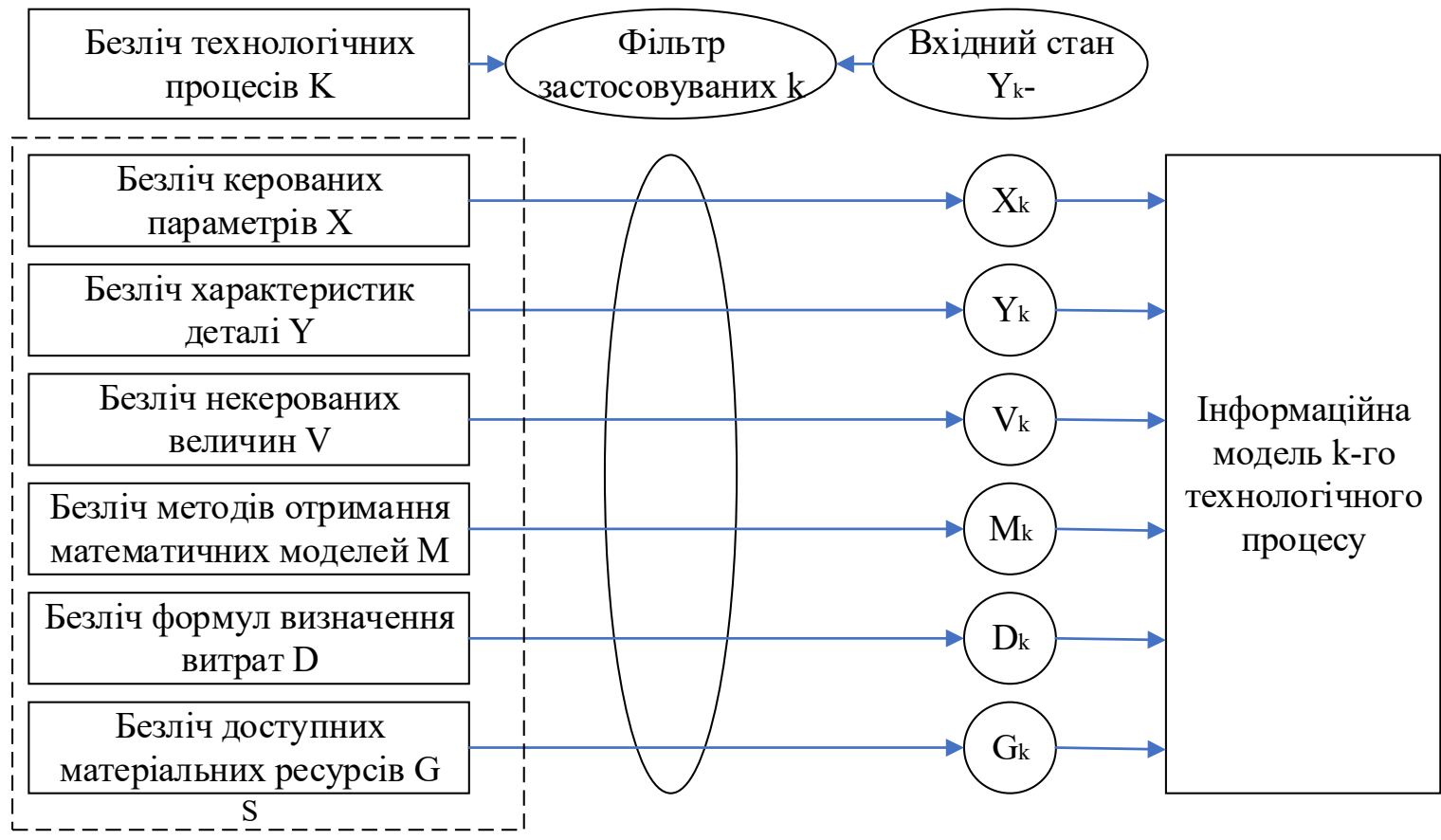

Рис. 5. Схема формування окремої інформаційної моделі технологічного процесу Джерело: розроблено авторами.

Формалізація рекомендаційних систем для забезпечення оптимізації ланцюга технологічних процесів як надбудови експертної системи над експертними системами окремих технологічних процесів вимагає використання послідовності технологічних процесів. Наприклад, деталь з параметрами $Y_{k}$ після кожного 3 технологічних процесів обробки має вигляд $Y_{k-1}$ згідно введеним позначенням. Це формує ланцюг технологічних операцій

$$
Y=\sum_{(k)} \vec{Y}_{k}
$$

де $k €$ екземпляром комбінаторної конфігурації 3 доступних технологічних процесів, а $(k-1)$ позначає попередній технологічний процес.

На основі (3) можна проілюструвати цикл обробки як граф доступних процесів (рис. 6). 


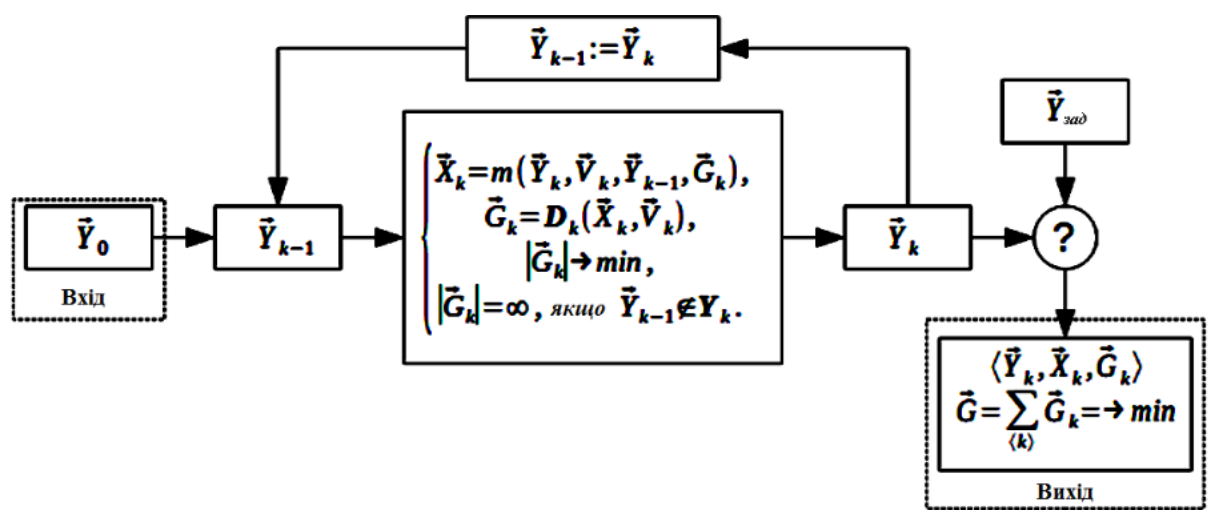

Рис. 6. Схема інформаційної моделі побудови ланцюга технологічних процесів Джерело: розроблено авторами.

\section{Структурна модель інформаційної системи підтримки технологічних процесів}

Структурно вся інформаційна система $S$ і кожна $з$ їі підсистем можуть бути описані в наступному вигляді:

$$
S=I\left\{S_{i}\right\}, i=0,1, \ldots, k,
$$

де функція $I$ - множина інформації, яка описує інформаційну систему як цілісну систему, що складається із $S$;

\section{$S_{i}$ - множина підсистеми $S$.}

Будь-яка підсистема $S$, знову ж може бути представлена і вигляді:

$$
S=I\left\{S_{i j}\right\}, i=0,1, \ldots, k,
$$

де $I\left\{S_{i j}\right\}$ - множина інформації, яка описує підсистему $S_{i}$ як цілісну систему, що складається із $S_{i j}$;

\section{$S_{i j}$ - множина підсистеми $S_{i}$.}

Цей процес структуризації повинен продовжуватися до тих пір, поки на деякому кроці множина підсистеми $S_{i j}, i=0,1, \ldots, k$ не виявиться пустою.

Дану структуризацію можна уявити у вигляді графу, де вузол описується двома параметрами $\left(I_{i j} K_{k}, S_{i j} K_{k}\right)$, а зв'язки - матрицею суміжності.

У відповідності до (4)-(5), структурну модель технологічного середовища (ТС) опишемо у вигляді:

$$
T C=\left\{I^{T}, M T\right\},
$$

де $I^{T}$ - множина інформацій, яка описує технологічне середовище як цілісну систему;

$M T$ - множина складових технологічного середовища.

Множина $M T$ може бути описана у вигляді:

$$
M T=\left\{T_{i} \in I^{T}\right\},
$$

де $T_{i}$-територіально-локалізовані складові технологічного середовища.

Множина $T_{i}$ може бути описана у вигляді:

$$
T_{i}=\left\{A_{i}, P_{i}\right\},
$$

де $A_{i}$ - множина апаратних засобів, $i$-го $T C$;

$P_{i}$ - множина програмних засобів, $i$-го $T C$.

Множина $A_{i}$ може бути описана у вигляді:

$$
A_{i}=\left\{I_{i}^{A},\left\{O_{i}, P_{r i}, C_{i}, t_{r i}, D_{i}\right\}\right\},
$$

де $I_{i}^{A}$-множина інформації, яка описує апаратні засоби $i$-го $T C$ як єдине ціле;

$O_{i}$ - множина засобів створення і обробки інформації;

$P_{r i}$ - множина засобів відображення і опису інформації;

$C_{i}$ - множина засобів управління інформацією;

$t_{r i}$ - множина засобів передачі інформації;

$D_{i}$ - множина засобів збереження інформації.

Множина $O_{i}$ може бути інтерпретована як множини комп'ютерів даного $T C$.

Множина $P_{r i}$ може бути описана у вигляді

$$
P_{r i}=\left\{\text { Dis }_{i}, \text { Din }_{i}, \text { Print }_{i}, P l_{i}\right\},
$$

де $D i s_{i}$ - множина дисплеїв даного $T C$;

$\operatorname{Din}_{i}$ - множина динаміків даного $T C$;

Print $_{i}$ - множина принтерів даного $T C$;

$P l_{i}$ - множина плотерів даного $T C$.

Множина $C_{i}$ може бути описана у вигляді:

$$
C_{i}=\left\{P c_{i}, M_{i}, K m_{i}\right\},
$$

де $P c_{i}$ - множина можливих пультів управління;

$M_{i}$ - множина маршрутизаторів;

$K m_{i}$ - множина комутаторів.

Множина $t_{r i}$ може бути описана у вигляді:

$$
t_{r i}=\left\{K n_{i}, m d_{i}, \text { int }_{i}, K_{T i}\right\},
$$

де $K n_{i}$ - множина каналів зв'язку;

$m d_{i}$ - множина модемів;

int $_{i}$ - множина інтерфейсів; 
$K_{T i}$ - множина концентраторів.

Множина $D_{i}$ може бути описана у вигляді:

$$
D_{i}=\left\{d_{i}, b n f_{i}, o p_{i}\right\},
$$

де $d_{i}$ - множина довгочасно запам'ятовуючих пристроїв;

$o p_{i}$ - множина оперативних запам'ятовуючих пристроїв;

$b n f_{i}$ - множина буферних накопичувачів.

При необхідності деталізація запропонованих структур може бути продовжена. Множина програмних засобів $i$-го ТС може бути описана у вигляді:

$$
P_{i}=\left\{I_{i}^{p},\left\{F_{i}, S_{i}, N_{i}\right\}\right\},
$$

де $I_{i}^{p}$ - множина інформації, яка описує програмні засоби $i$-го ТС як цілісної системи;

$F_{i}$ - множина функціональних програм;

$S_{i}$ - системне програмне забезпечення;

$N_{i}$ - мережне програмне забезпечення.

Множина $F_{i}$ може бути представлена у вигляді:

$$
F_{i}=\left\{F_{i}^{i}, F_{i}^{o}, F_{i}^{p}, F_{i}^{g}, F_{i}^{3}\right\},
$$

де $F_{i}^{i}$-множина функціональних програм, які виконують інформаційні функції;

$F_{i}^{o}$ - множина функціональних програм, які можуть виконувати функції обробки інформації;

$F_{i}^{p}$-множина функціональних програм, які можуть виконувати функції представлення інформації;

$F_{i}^{g}$-множина функціональних програм, які можуть обробляти графічну інформацію;
$F_{i}^{3}$ - множина функціональних програм, які можуть обробляти звукову інформацію.

Множина $S_{i}$ може бути описана у вигляді:

$$
S_{i}=\left\{S_{i}^{o n}, S_{i}^{c}, S_{i}^{d}, S_{i}^{t}\right\}
$$

де $S_{i}^{o n}$ - операційні системи АРМ;

$S_{i}^{c}$ - множина СУБд $i$-го ТС;

$S_{i}^{d}$ - множина програмних засобів захисту інформації;

$S_{i}^{t}$ - множина програмних засобів сервісного обслуговування і тестування.

Множина $N_{i}$, може бути описана у вигляді:

$$
N_{i}=\left\{C_{i}^{l}, M_{i}^{p}, B_{i}^{p}, d p_{i}, N_{i}^{E}, N_{i}^{d}\right\},
$$

де $C_{i}^{l}$-Множина протоколів управління лінією передачі даних;

$M_{i}^{p}-$ множина протоколів маршрутизації;

$B_{i}^{p}-$ множина протоколів буферизації;

$d p_{i}$ - множина протоколів диспетчерського управління (управління режимами функціонування мережі);

$N_{i}^{E}$ - множина протоколів міжмережевої взаємодії, (протоколи взаємодії через шлюзи у зв'язку з несумісністю довільних мереж);

$N_{i}^{d}$-міжмережеві протоколи захисту інформації.

Подальша деталізація складових програмного забезпечення можлива тільки у вигляді обширних каталогів. Графова модель буде мати вигляд, представлений на рис. 7 .

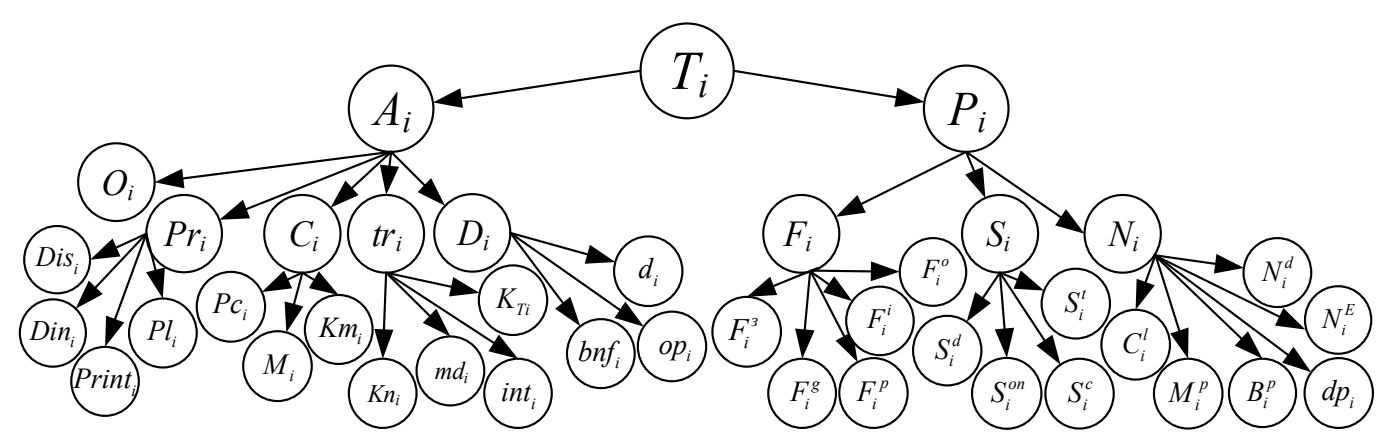

Рис. 7. Графова модель

Джерело: розроблено авторами.

Користувацьке середовище - сукупність організацій та фізичних осіб, діяльність яких пов'язана 3 функціонуванням інформаційного середовища. Аналогічним чином можуть бути структуровані інформаційне, користувацька та робоче середовище. Інформаційне середовище - сукупність розміщених на різних носіях інформаційних ресурсів, які обробляються за допомогою відповідних засобів технологічного середовища.

Складові інформаційного середовища:

$B_{i}$ - бази даних; $K_{i}$ - каталоги; $\Phi_{i}-$ файли $i$ го рівня ієрархії. 
3 наведених міркувань можна зробити висновок, що спеціалізована структурна модель інформаційної системи може бути описана в наступному вигляді:

$$
\begin{gathered}
S=\{I C, T C, K C, P C\}= \\
=\left\{B, K, \Phi, O, P_{r}, C, t_{r}, D, F, S, N, B_{T}, B_{H}, T_{P}, K_{T P}\right\}= \\
=\left\{B, K, \Phi, O, D_{i s}, D_{i n}, P_{r \text { int }}, P_{i}, P_{c}, M, K_{m}, K_{n},\right. \\
m d, i n t, K_{T}, d, b n f, o p, F^{i}, F^{o}, F^{p}, F^{g}, F^{3}, \\
S^{o n}, S^{c}, S^{d}, S^{t}, C^{l}, M^{p}, B^{p}, d p, N^{E}, N^{d}, T, \\
\left.A, O_{n}, C_{o n}, \Pi, E, P, B, O_{i}, T_{p}, T_{T P}, \Pi_{M}, K_{n}\right\} .
\end{gathered}
$$

Побудова структурної системи підтримки прийняття рішень технологічного процесу

На основі розглянутих та розроблених методів та механізмів, які використовують для розробки технологічних процесів розглянуто структуру інформаційної системи підтримки прийняття рішень для автоматизації створення оптимізованих технологічних процесів яку показано на рис. 8. Систему умовно можна поділити на наступні етапи.

Перший етап призначений для формалізації вимог до результатів технологічного процесу та визначення вхідних параметрів деталі, яка підлягає обробці.

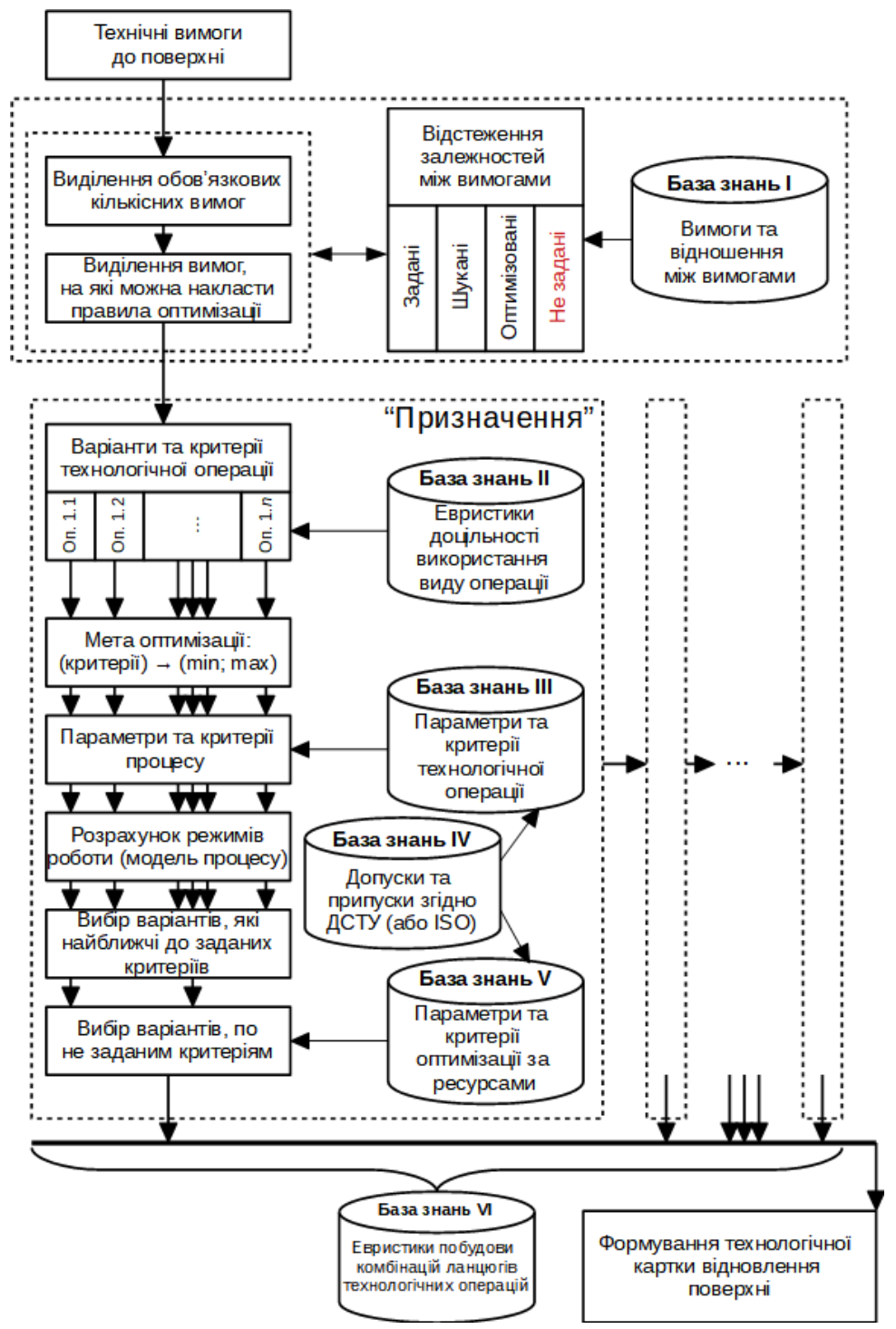

Рис. 8. Схема функціонування інформаційної системи підтримки рішень для автоматизації створення оптимізованих технологічних процесів Джерело: розроблено авторами.

При цьому виділяються вимоги до результату обробки та критерії оптимізації. При недостатній кількості критеріїв або вимог, евристичними правилами першої групи вводяться обмеження а також критерії оптимізації низького пріоритету. 3 причини можливості існування конфліктів у вимогах, що повинно відображатися в базі знань по відношенню між вимогами, проводиться заміна критеріїв на критерії оптимізації з підвищеним пріоритетом. В результаті не задані критерії та вимоги переводяться в 
розряд слабких критеріїв оптимізації. Шукані вимоги відповідають за порядок технологічних операцій при виконанні технологічного процесу та параметрів, режимів проведення технологічних операцій.

В більшості ситуацій шукані параметри переходять у формування технологічної картки процесу.

Другий етап є структурною оптимізацією, яка має визначити допустимі ланцюги технологічних операцій. Але в складних технологічних процесах 3 великою кількістю операцій ця задача має комбінаторну складність, що призводить до непомірно великої кількості можливих рішень, які не можна розглянути за розумний інтервал часу. Значно скоротити кількість розглянутих комбінацій можна завдяки використанню евристичних правил, які враховують технічне призначення технологічної операції.

Це виражено в формуванні евристичних правил груп 2 та 3 . Де друга група визначає призначення операції, а третя - відношення порядку та рівності між операціями. Відношення рівності застосовне у випадках, коли одна технологічна операція може виконати кілька призначень. В разі об'єднання або зміни технологічних операцій можуть виникати додаткові параметри та критерії обробки, що відображено в евристичних правилах четвертої групи.

Тому наступним етапом оптимізації є використання фільтру доцільності операції та процесу додавання критеріїв вимог, що не завжди можна повністю автоматизувати. Проте цей етап гарантує, що додаткові параметри та критерії не будуть втрачені при побудові технологічного процесу.

В результаті проведення процесу оптимізації технологічного процесу за допустимими евристичними правилами, отримуємо множину ланцюгів окремо оптимізованих технологічних процесів, 3 якої проводиться багатокритеріальній відбір, що відповідає поставленим вимогам оптимізації. Користувач системи може отримувати у відповідь як і одну картку технологічного процесу, так і декілька найкращих.

\section{Висновки}

Дослідження, проведені в даній роботі, дозволили розробити модель реалізації структури технологічного процесу у хмарному сервісі. В рамках розробки були отримані наступні результати:

1. Було розроблено модель реалізації структури технологічного процесу, для якої було визначено основні вхідні параметри: перелік параметрів, які впливають на процес; перелік параметрів, які є результатом процесу; перелік керованих параметрів; перелік некерованих параметрів; перелік невідомих параметрів; деталізована структура технологічного процесу з розділенням параметрів та результатів. Також була запропонована структура експертної системи для оптимізації технологічних процесів, проаналізовані методи представлення знань та відповідно розроблено схему потоків інформації під час реалізації даної експертної системи.

2. На основі розглянутих та розроблених методів та механізмів, які використовують для розробки технологічних процесів розроблено структуру інформаційної системи підтримки прийняття рішень для автоматизації створення оптимізованих технологічних процесів.

3. За допомогою використання розроблених методів та моделей, в результаті проведення процесу оптимізації технологічного процесу за допустимими евристичними правилами, вдається отримати множину ланцюгів окремо оптимізованих технологічних процесів, з якої проводиться багатокритеріальний відбір, що відповідає поставленим вимогам оптимізації. Користувач системи може отримувати у відповідь як і одну картку технологічного процесу, так і декілька найкращих.

Таким чином розроблена у даній роботі модель реалізації структури технологічного процесу дозволяє у подальшому оптимізувати високотехнологічні процеси підприємств різного масштабу з використанням хмарних інформаційних технологій.

\section{Список літератури}

1. Смирнов А. А., Смирнова Т. В., Дреев А. Н., Дудан А. В. Оптимизация технологического процесса восстановления и упрочнения поверхностей с заданными характеристиками в виде облачного сервиса. Вестник Полоикого государственного университета. 2020. № 3. С. 50-61.

2. Смірнова Т. В. Формування евристичних правил, бази знань та формалізація структури й правил технологічного процесу для оптимізаційної хмарної інформаційної системи. Системи управління, навігації та зв'язку. 2020. № 2(60). C. 101-104.

3. Анфёров М. А., Селиванов С. Г. Структурная оптимизация технологических процессов в машиностроении. Уфа : Гилем, 1996. 185 с.

4. Попов М. Е., Абухарб М. Система поддержка принятия решения при выборе метода упрочняющей обработки деталей машин в интегрированных САПР. Вестник Донского государственного технического университета. 2011. № 11(3). C. 333-342.

5. Скрипка К. И., Зенкин М. А. Экспертная система автоматизированного выбора способов восстановления сработанных деталей. Вестник Житомирского дорожно-технического университета. 2004. № 1(28). С. 66-68.

6. Смірнова Т. В. Формалізація та реалізація структури технологічного процесу електродугового напилення для оптимізаційної експертної системи. Технічні науки та технології. 2020. № 1(19). С. 104-113.

7. Смірнова Т. В., Минайленко Р. М., Доренський О. П., Сисоєнко С. В., Смірнов С. А. Хмарна автоматизована си- 
стема інтелектуальної підтримки прийняття рішень для технологічних процесів. Вісник Черкаського державного технологічного університету. 2021. № (4). С. 84-92.

8. Попов М. Е. Основы САПР технологических операций упрочняющей обработки: учеб. пособие. Ростов на Дону : РИСХМ, 1987.91 с.

9. Попов М. Е. Формализованное описание структуры базы данных методов упрочняющей обработки в интегрированных САПР. Вестник Житомирского дорожно-технического университета. 2000. № 2. С. 88-91.

10. Горелова Г. В., Здор В. В., Свечарник Д. В. Метод оптимума номинала и его применение. Москва : Энергия, 1970. $200 \mathrm{c}$

11. Попов М. Е., Попов А. М. Разработка и постановка продукции на производство на основе структурирования функции качества. Вестник машиностроения. 2000. № 7. С. 52-58.

12. САПР. Типовые математические модели объектов проектирования в машиностроении : метод. указания. РД 50464-84. Москва : Стандарты, 1985. 200 с.

13. Попов М. Е., Попов А. М. Интеграция конструкторского и технологического проектирования на основе концепции Concurrent Engineering. Вестник машиностроения. 1998. № 4. С. 41-45.

14. Вереск О. М. Технологии поддержки принятия решений. Львов : Изд-во Львов. политех., 2013. 101 с.

15. Лимаренко В. В. Информационная система поддержки решений для автоматизации создания технологических процессов механообработки деталей высокоточного оборудования : дис. канд. техн. наук. Харьков, 2019.

16. Хох В. Д., Мелешко Е. В., Якименко М. С. Исследование методов построения экспертных систем. Сucmeмы управления, навигащии и связи. 2016. № 4(40). С. 48-52.

Надійшла до редколегії 10.08.2021

Схвалена до друку 16.11.2021

\section{Відомості про авторів:}

\section{Смірнова Тетяна Віталіївна}

кандидат технічних наук доцент доцент Центральноукраїнського національного технічного університету, Кропивницький, Україна https://orcid.org/0000-0001-6896-0612

\section{Столяренко Микола Петрович} провідний науковий співробітник Науково-дослідного центру ракетних військ і артилерії, Суми, Україна https://orcid.org/0000-0003-4737-9110

\section{Янков Микита Олегович}

аспірант

Центральноукраїнського національного технічного університету,

Кропивницький, Україна https://orcid.org/0000-0002-4188-9032

\section{Грудік Віктор Вікторович} аспірант

Центральноукраїнського національного технічного університету, Кропивницький, Україна https://orcid.org/0000-0003-4563-048X

\section{Моторін Юрій Юрійович} аспірант

Центральноукраїнського національного технічного університету, Кропивницький, Україна https://orcid.org/0000-0003-0368-8042

\section{Information about the authors:}

\section{Tetiana Smirnova}

$\mathrm{PhD}$ in Engineering Associate Professor

Associate Professor of Central

Ukrainian National Technical University, Kropyvnytskyi, Ukraine https://orcid.org/0000-0001-6896-0612

\section{Mykola Stolyarenko}

Leading Researcher

of Research Center

for Missile Forces and Artillery,

Sumy, Ukraine

https://orcid.org/0000-0003-4737-9110

\section{Mykyta Yankov}

Post-Graduate

of Central Ukrainian National

Technical University,

Kropyvnytskyi, Ukraine

https://orcid.org/0000-0002-4188-9032

\section{Viktor Hrudik}

Post-Graduate

of Central Ukrainian National

Technical University,

Kropyvnytskyi, Ukraine

https://orcid.org/0000-0003-4563-048X

\section{Yurii Motorin}

Post-Graduate

of Central Ukrainian National

Technical University,

Kropyvnytskyi, Ukraine

https://orcid.org/0000-0003-0368-8042 


\section{МОДЕЛЬ РЕАЛИЗАЦИИ СТРУКТУРЫ ТЕХНОЛОГИЧЕСКОГО ПРОЦЕССА В ОБЛАЧНОМ СЕРВИСЕ}

Т.В. Смирнова, Н.П. Столяренко, Н.О. Янков, В.В. Грудик, Ю.Ю. Моторин

В работе разработана модель реализачии структуры технологического прочесса в облачном сервисе, для которой были определены основные входные параметры: перечень параметров, которые влияют на прочесс; перечень параметров, которые являются результатом процесса; перечень управляемых параметров; перечень неуправляемых параметров; перечень неизвестных параметров; детализирована структура технологического прочесса с разделением параметров и результатов. Предложена структура экспертной системы для оптимизации технологических процессов, проанализированы методы представления знаний и соответственно разработана схема потоков информации при реализации данной экспертной системы. На основе рассмотренных и разработанных методов и механизмов, используемых для разработки технологических процессов, разработана структура информационной системы поддержки принятия решений для автоматизации создания оптимизированных технологических процессов. С помощью использования разработанных методов и моделей, в результате проведения процесса оптимизации технологического процесса по допустимым эвристическим правилам, удалось получить множество иеепей отдельно оптимизированных технологических прочессов, с которой проводится многокритериальной отбор, соответствует предъявляемым требованиям оптимизации. Пользователь системы может получать в ответ как одну карточку технологического процесса, так и несколько лучших. Таким образом, разработанная в данной работе модель реализачии структуры технологического проиесса позволяет в дальнейшем оптимизировать высокотехнологичные процессы предприятий разного масштаба по использованию облачных информационных технологий.

Ключевые слова: система поддержки принятия решений, технологические процессы, облачные сервисы.

\section{MODEL OF REALIZATION OF STRUCTURE OF TECHNOLOGICAL PROCESS IN CLOUD SERVICE}

T. Smirnova, M. Stolyarenko, M. Yankov, V. Hrudik, Yu. Motorin

The paper develops a model for the implementation of the structure of the technological process in the cloud service, for which the main input parameters were determined: a list of parameters that affect the process; a list of parameters that are the result of the process; list of managed parameters; list of unmanaged parameters; list of unknown parameters; detailed structure of the technological process with the separation of parameters and results. The purpose of the formation of a model for the implementation of the structure of the technological process is to ensure the possibility of creating universal algorithms and programs regarding the initial and final conditions regarding the shape and size of parts, the nature of production, characteristics of equipment and equipment, the design of various technological processes for parts of different classes and of any complexity and their implementation through the cloud service. The structure of the expert system for optimization of technological processes is offered, the methods of knowledge presentation are analyzed and accordingly the scheme of information flows during the realization of this expert system is developed. Based on the considered and developed methods and mechanisms used for the development of technological processes, the structure of the information system of decision support has been developed to automate the creation of optimized technological processes. Using the developed methods and models, as a result of the process optimization process according to acceptable heuristic rules, it was possible to obtain a set of chains of separately optimized technological processes, from which multicriteria selection is performed that meets the optimization requirements. The user of the system can receive in return both one card of technological process, and some best. Thus, the model of realization of the structure of the technological process developed in this work allows to further optimize high-tech processes of enterprises of different scales with the use of cloud information technologies.

Keywords: decision support system, technological processes, cloud services. 